\title{
Aliphatic Hydrocarbons in Recent Dated Sediment Cores of Imo River, SE Nigeria: Environmental/Historical Implications
}

\author{
Inyang O. Oyo-Ita ${ }^{1}$, Unyime U. Umoh ${ }^{2,3}$, Ugim S. Ugim ${ }^{1}$, Emmanuella E. Oyo-Ita $^{4}$ \& Orok E. Oyo-Ita ${ }^{1}$ \\ ${ }^{1}$ Environmental/Petroleum Geochemistry Research Group, Department of Pure and Applied Chemistry, \\ University of Calabar, Calabar, Nigeria \\ ${ }^{2}$ State Key Laboratory of Marine Geology, School of Ocean and Earth Sciences, Tongji University, Shanghai, \\ China \\ ${ }^{3}$ Atlantis Oceanographic Society Akwa Ibom State, Nigeria \\ ${ }^{4}$ Department of Chemical Science, Cross River University of Technology, Calabar, Nigeria \\ Correspondence: Inyang O. Oyo-Ita, Environmental/Petroleum Geochemistry Research Group, Department of \\ Pure and Applied Chemistry, University of Calabar, Calabar, Nigeria. Tel: 234-70-6944-8090. E-mail: \\ inyangoyoita@yahoo.com
}

Received: October 23, 2019

Accepted: December 8, 2019 Online Published: March 31, 2020

doi:10.5539/ep.v9n1p26

URL: https://doi.org/10.5539/ep.v9n1p26

\begin{abstract}
Four recent sediment cores (0-30 cm long) from Afam (AF), Mangrove (MG), Estuary (ES) and illegal Petroleum refinery (PT) sites of the Imo River, Southeastern Nigeria were analyzed to characterize the sources and distribution of organic matter $(\mathrm{OM})$, as well as examine their historical trends of deposition and assess human-induced changes in the last ca. 5 decades using biomarker approach. Radionuclides ${ }^{210} \mathrm{~Pb}$ and ${ }^{137} \mathrm{Cs}$ were used to assign approximate dates to each section of the cores. Evaluation of proxy parameters such as carbon preference index (CPI, 2.01 - 2.19), carbon number maximum $\left(\mathrm{C}_{\max }, 29,31\right)$ and atomic $\mathrm{C} / \mathrm{N}(16.51-31.32)$ for the most recent top layers $(0-5 \mathrm{~cm})$ revealed greater wash-in of land-derived organic matter $(\mathrm{OM})$, attributable to the recent rise in water height. The bottom layer (PT1, 25-30 cm,) of the PT core deposited ca. 1964-1972 exhibited a CPI of 0.97 and pristane/phytane $(\mathrm{Pr} / \mathrm{Ph}, 3.75)$, suggesting that oil bunkering/illegal refinery activity had begun in the region ca. 8 years after the first commercial discovery of oil in Nigeria in 1956. The occurrence in high abundance of heptadecane in the middle layer (ES4, 10-15 cm) of the ES almost corresponded with the period of eutrophication that blocked the waterway in the late 1980s. Measurement of a marked unresolved complex mixture at the near-top layer (AF5, 5-10 cm) of the AF indicated that the heaviest contamination by petroleum hydrocarbons occurred at ca. 1997-2005. This time frame coincided with the period of intensive bunkering and oil pipeline vandalism by Niger Delta militant groups.
\end{abstract}

Keywords: biomarker, aliphatic hydrocarbons, historical trend, source, Imo River

\section{Introduction}

Allochthonous and autochthonous organic matter (OM) are deposited in the ocean margins and shelves rivers at a rapid rate (Saliot et al. 2001). Several studies showed that OM transported by tropical rivers/estuaries are mainly degraded terrestrial materials (Ittekkot 1988). Recently, the understanding of OM sources, distribution and fate in aquatic environment have received significance scientific attentions (Jaffé et al. 2005).

Particularly, aliphatic hydrocarbons are biomarkers substantially used to classified OM origins from terrestrial to marine environment (Camacho-Ibar et al. 2003; Oyo-Ita et al. 2010, 2016). As a major contributor to OM flux, tracing the sources of aliphatic hydrocarbons in the study area will help in the understanding of global dynamics of OM delivery.

The present study is part of the regional project aimed at understanding the sources, transport and fate of lipid biomarkers in the Niger Delta drainage basin.

As time has progressed, the deposition of hydrocarbons led to changes in the quality and quantity of OM influx at different sediment depths. Previous studies indicate that the contamination characteristics of certain organic contaminants in sediments are clearly diverse in different years due to industrial development and changes in the 
energy condition of the environment (Guo et al. 2010; Oyo-Ita et al. 2017). Therefore, it is important to examine the historical trends in aliphatic hydrocarbons deposition in sediment cores. Extensive studies of temporal trends in aromatic hydrocarbons deposition in sediment cores have been documented worldwide (eg. Guo et al. 2010; Zhang et al. 2013; Oyo-Ita et al. 2017) and most reveal a good correlation between these trends and their vertical distributions. However, knowledge of such a correspondence in the case of aliphatic hydrocarbons is scarce, particularly for the tropical sub-saharan African sedimentary environment. The present study is the first investigation of historical trends in aliphatic hydrocarbons deposition in dated sediments from the Imo River aimed at identifying the effect of human activity/climate change on the study area over the last few decades. Previous organic geochemical studies of the river sediment focused mainly on the surface sediment samples including the distributions and sources of petroleum hydrocarbons (Oyo-Ita et al. 2016), polycyclic aromatic hydrocarbons (PAHs) in sediments and soils from oil exploration areas (Sojino et al. 2010), distribution of fossil fuel biomarkers (Ekpo et al. 2012) and fatty acids and alkanols distribution and sources (Oyo-Ita and Oyo-Ita 2013) as well as toxicological assessment of PAHs (Oyo-Ita et al. 2017). The present report was intended to chronicle the natural and humans-induced events that occurred after the period of oil discovery in commercial quantity in Nigeria in 1956 to ca. 2014 after the offer of amnesty to the Niger Delta Militant groups by the Nigerian government using aliphatic hydrocarbon biomarkers.

The main objectives of the present study were to: (i) determine the age of the sediment interval under study, (ii) characterize the sources and distribution of aliphatic hydrocarbons in the sediment, (iii) evaluate the historical trends in their deposition and (iv) identify the effects of humans-induced/climate changes in the study area.

\subsection{Study Area}

Details about the study area was described by Oyo-Ita and Oyo-Ita (2013). Briefly, the Imo River is a major river found in the southeastern Niger Delta, Nigeria (Fig. 1), located between $5^{\circ} 55^{\prime} \mathrm{N}$ and $7^{\circ} 1^{\prime} \mathrm{E}$. The depth of the river is less than $20 \mathrm{~m}$ character by flood and ebb tides. The topography of the river is sloping and flooded (Ezeayim and Okereke 1996), especially during intensive rainfall. In March 2012, the Nigerian hydrological service announced an impending rise in water height to about $5 \mathrm{~m}$ occasioned by global climate change that subsequently caused devastating consequences to life and properties of coastal communities who ignored an early warning of evacuation from the region to the hinterland. The vegetation of the river bank includes grasses, mangroves and other terrestrial higher plants. A few industrial activities are also found along the river (Afam Power Station). However, illegal oil refinery and bunkering activity can be seen along the river bank resulting in oil spillage.

\section{Materials and Methods}

\subsection{Materials and Quality Control/Assurance}

$n$-Hexane, methanol $(\mathrm{MeOH})$ and acetone $\left(\mathrm{Me}_{2} \mathrm{CO}\right)$ were analytical grade solvents provided by Dr. Ehrenstofer $\mathrm{GmbH}$ (Augsburg, Germany) and Merck (Hohenbrunn, Germany). Alumina $\left(\mathrm{Al}_{2} \mathrm{O}_{3}\right.$; active neutral 0.063-0.200 $\mathrm{mm})$, silica gel $\left(\mathrm{SiO}_{2} ; 0.063-0.200 \mathrm{~mm}\right)$ and anhydrous sodium sulfate $\left(\mathrm{Na}_{2} \mathrm{SO}_{4}\right)$ were also from Merck. The external standard (perdeuterotetracosane) used for quantification: was from Cambridge Isotope Laboratory; Ambovar, USA.

All glassware used was cleaned initially with $\mathrm{Me}_{2} \mathrm{CO}$. It was heated at $300{ }^{\circ} \mathrm{C}$ overnight to decompose any trace of $\mathrm{OM}$ and finally rinsed with $\mathrm{Me}_{2} \mathrm{CO}$. One procedural blank was analyzed accompanying every batch of 2-5 samples to correct for background contamination during the preliminary steps of purification and extraction. Analysis of the samples was repeatedly carried out in triplicate and relative standard deviation values were calculated. Blanks were processed together with samples. Limits of quantification (LOQ) and limits of detection (LOD) values were calculated as the mean signal of the blanks plus 10x the standard deviation of the blank signals and mean signal of the blanks plus $3 \mathrm{x}$ the standard deviation of the blank signals, respectively.

\subsection{Samples}

The Imo River was divided into four different sampling sites on the basis of its characteristic features (Fig. 1). Each core $(30 \mathrm{~cm})$ was designed to cover the period of the first commercial oil discovery in Nigeria in 1956 to a time after the Federal government offered an amnesty to the Niger Delta militant groups in 2009.

Samples were collected after the devastating flood episode of 2012. Site I corresponded to a core obtained near thick mangrove vegetation (MG), Site II corresponded to a core collected near the Afam power station (AF) where natural gas combustion for power generation takes place. Site III corresponded to a core collected upstream near an illegal local petroleum refinery (PT) and Site IV to a core collected towards the estuary (ES) where fishery activity takes place. For each coring site, an additional core was collected for radiometric dating 
using a box corer and carefully sealed in plastic bags to preserve the mud-line. For sediment characterization, each core was cut into 6 sections of $5 \mathrm{~cm}$ intervals, wrapped with pre-cleaned $\mathrm{Al}$ foil, labeled, kept in a cooler containing ice and brought to the laboratory and stored at $-20^{\circ} \mathrm{C}$ in a deep freeze until further processing.

\subsection{Grain Size, Bulk Density and Elemental Analysis}

Sediment grain sizes were analyzed as reported by Strauss et al. (2015) 'using a laser particle sizer (LS 200, Beckmann-Coulter) with a mesh range of 0.375-1000 $\mu \mathrm{m}$ '. Bulk density (BD) measurements were performed by determining the volume of frozen samples with the Archimedes Principle that involved quantifying the water displaced in a water-filled glass beaker using a balance (FCB 8K0.1, Kern; Arnaud et al., 2006). BD was calculated using the following equation:

$\mathrm{BD}\left[10^{3} \mathrm{kgm}^{-3}\right]=$ sample dry weight $\left[10^{3} \mathrm{~kg}\right] / \mathrm{sample}$ volume $\left[\mathrm{m}^{3}\right]$.

More so, Total organic carbon (TOC) and total nitrogen (TN) were determined as previously reported by Oyo-Ita et al. (2016) 'using flash combustion at $1024^{\circ} \mathrm{C}$ and thermal conductivity detection in triplicate with a CHNS Elemental Analyser (Carlo Erba 1108;). Pre-weighed freeze-dried samples were de-carbonated in $87 \%$ syrupy $\mathrm{H}_{3} \mathrm{PO}_{4}$ repeatedly until bubbling stopped and were rinsed in de-ionized water until neutral. The samples were dried in an oven and reweighed. The difference between the initial and final weights multiplied by 100 was taken as the total inorganic carbon (TIC) content.

\subsection{Radiometric Analysis}

Detailed method of radiometric analyses is given in Appleby et al. (1992) and Pinglot and Pourchet (1995). As described by these authors, 'radiometric measurements were performed in a very low background P-type germanium well detector (Canberra Industries), which offered a relative efficiency of $40 \%$ and a $4 \pi$ counting geometry. The counting device was placed in a low-level background laboratory, in order to ensure a very low detection threshold for environmental radioactivity. Such a precaution was particularly necessary for the isotopes of interest here $\left({ }^{210} \mathrm{~Pb},{ }^{214} \mathrm{~Pb},{ }^{137} \mathrm{Cs}\right.$ and $\left.{ }^{241} \mathrm{Am}\right)$ '. Furthermore, Arnaud et al. (2006) explained that 'this analytical process allowed the measurement of ${ }^{137} \mathrm{Cs}$ and ${ }^{210} \mathrm{~Pb}$ isotopes with detection limits of below $6 \mathrm{mBq} / \mathrm{g}$. The experimental errors for this measurement, taking into account the different sources of error due to the sampling and analytical procedures, was approximately $\pm 20 \%$ for ${ }^{137} \mathrm{Cs}$ and ${ }^{210} \mathrm{~Pb}$ and $\pm 50 \%$ for ${ }^{241} \mathrm{Am}$. Counts were carried out on individual samples for time periods ranging from $10^{5}$ to $3 \times 10^{5} \mathrm{~s}$. For every 10 samples analyzed, the background level was measured over periods of $2 \times 10^{5}$ to $3 \times 10^{5} \mathrm{~s}$. Sample specific activity A, and total uncertainties of calculated specific activity values, $\S \mathrm{A}$, were expressed in Becquerel per kilogram of dry weight (Bq $/ \mathrm{kg}$ dry wt). The standard deviation expressed the $95 \%$ confidence level'.

\subsection{Extraction and Clean- $U p$}

Prior to extraction, a standard solution containing the target compounds were spiked onto the samples. An aliquot $(1 \mathrm{~g})$ each of sediment was extracted $3 \mathrm{x}$ using ultrasonic bath for $30 \mathrm{~min}$ with $15 \mathrm{ml}\left(\mathrm{Me}_{2} \mathrm{CO}: n\right.$-hexane; $1: 1 \mathrm{v} / \mathrm{v})$. All extracts were combined and concentrated to near-dryness with rotary evaporator. The total extract were re-dissolved in hexane and separated into non-polar and polar fractions with $n$-hexane and DCM:MeOH $(1: 1 \mathrm{v} / \mathrm{v})$ respectively using a short glass column packed with $\mathrm{Al}_{2} \mathrm{O}_{3}$ prior to gas chromatography-mass spectrometry (GC-MS).

\subsection{Instrumental Analysis}

Analysis of the non-polar fraction was conducted as earlier reported by Oyo-Ita et al. (2010). 'GC-MS Thermo-Finnigan TRACE (Manchester, UK) in the electron impact (EI) mode at $70 \mathrm{eV}$. A 30-m, 0.25-mm-id column coated with $0.25 \mu \mathrm{m}$ of ZB-5MS stationary phase (Phenomenex Zebron; USA) was used. The carrier gas was $\mathrm{He}$ at a constant $1.2 \mathrm{ml} / \mathrm{min}$. The injector temperature, in "splitless" mode, was $280{ }^{\circ} \mathrm{C}$ and the purge valve was activated $50 \mathrm{~s}$ after injection. Column temperature program was $60^{\circ} \mathrm{C}$ (for $1 \mathrm{~min}$ ) to $200^{\circ} \mathrm{C}$ at $10^{\circ} \mathrm{C} / \mathrm{min}$ and finally to $320{ }^{\circ} \mathrm{C}$ (held $10 \mathrm{~min}$ ) at $4.8^{\circ} \mathrm{C} / \mathrm{min}$. Transfer line and ion source were at $250{ }^{\circ} \mathrm{C}$ and $200{ }^{\circ} \mathrm{C}$, respectively. Data were processed with the X-calibur Thermo Finnigan software (San Jose, California, USA) and acquired in the full scan and selected ion monitoring (SIM) modes with 6 min of solvent delay. Compounds assignment was on the basis of retention time and ion fragmentation pattern comparison with biomarker standards. Quantification was performed from SIM peak area conversion to compound mass using peak area of the external standard: perdeuterotetracosane for alkanes and hopanes. Surrogate data were used to calculate loss during the analysis (ie. for recovery purposes). The recovery study $(n=3)$ was carried out by spiking a standard solution containing the target compounds onto a silica matrix to determine their loss during the analytical procedure. The average recovery was $85 \pm 0.98 \%(60-130 \%)$. 


\section{Results and Discussion}

\subsection{Sediment Bulk Characteristics}

As presented in S1-1 and Fig. 2, results of sediment bulk properties including pH, grain size distribution, bulk density, TOC and TN did not vary significantly within each core and among the four cores. However, the three coring sites still provided evidence of sedimentary and historical events. These events were characterized by a change in grain size/bulk density at the top layers (SI-1) and inundation of the lower layers by petroleum hydrocarbons/algal OM in the last few decades, respectively.

The cores were dominated by gray-dark sandy silt and a minor clay deposits at depths between 5 and $30 \mathrm{~cm}$, whereas a relatively higher silt/clay fraction were found at the top layers $(0-5 \mathrm{~cm})$. The fairly constant bulk density values recorded for the lower layers (SI-1) suggest that a steady sedimentation rates prevailed at the three coring sites. However, the slight drop in bulk density values at the top layers $(0-5 \mathrm{~cm})$ was linked to the flood episode of 2012, leading to a slight change in the sedimentation rates at the top layers.

The sediment cores were dated by the application of ${ }^{210} \mathrm{~Pb}$-derived model and validated by ${ }^{137} \mathrm{Cs}$-derived model. The ${ }^{210} \mathrm{~Pb}_{\mathrm{xs}}$ specific activity profiles were relatively homogeneous for depths of between 5 and $30 \mathrm{~cm}$ (3.06-3.24 $\mathrm{Bq} / \mathrm{kg})$ and differed at $0-5 \mathrm{~cm}\left((4.24-4.35 \mathrm{~Bq} / \mathrm{kg}\right.$; SI- 1$)$. The ${ }^{137} \mathrm{Cs}_{\mathrm{xs}}$ specific activity reached maximum at $0-5$ $\mathrm{cm}(5.08-5.12 \mathrm{~Bq} / \mathrm{kg})$ and then similarly became relatively homogenous in the underlying sample layers (5-30 $\mathrm{cm}$; 3.09-3.28 Bq/kg; SI-1). The depths at which ${ }^{210} \mathrm{~Pb}_{\mathrm{xs}}$ and ${ }^{137} \mathrm{Cs}_{\mathrm{xs}}$ specific activities were homogenous coincided with the depths $5-30 \mathrm{~cm}$ and differed from depth $0-5 \mathrm{~cm}$ in which the relatively higher silt/clay content and slight decrease in bulk density was found (SI-1). Consequently, the sediment deposits scenario did not meet the conditions for applying the CFCS model (Arnaud et al. 2006). Therefore, CFCS could not be used to calculate mean sedimentation rates for the cores. The calculated ages based on CRS model assumed the constant sedimentation rates for the whole cores. These sedimentation rates were derived from the mean slope of ${ }^{210} \mathrm{~Pb}$ and ${ }^{137} \mathrm{Cs}$ specific activities plotted on a logarithmic scale. Mean sedimentation rates for AF, PT and MG cores were ca. $0.60,0.58$ and $0.62 \mathrm{~cm} / \mathrm{yr}$, respectively, with an overall mean of ca. $0.60 \pm 0.07 \mathrm{~cm} / \mathrm{yr}$. This overall mean value was subsequently used to evaluate the historical variations of aliphatic hydrocarbons in the river sediment.

Ages of specific layers were determined by dividing their depths by the corresponding sedimentation rates. Age resolution of the cores represents an average provisional record of ca. 50 yr. of sedimentation history. Sedimentary records for the river date from ca. 1964 (ca. 8 yr after first commercial discovery of oil in Nigeria in 1956) to ca. 2014 (ca. 5 yr after an amnesty offer to Niger Delta militant groups by the Nigerian government in 2009).

Low TOC values were found in all layers of the cores (Fig. 2 a). The TOC content of AF was in the range 0.56 $1.02 \%$, maximizing in the near-top layer (AF5, $5-10 \mathrm{~cm}$, ca. 1997-2005) and a minimum at the middle layer (AF3, 15-20 cm, ca. 1989-1997, Fig. 2 a). A TOC range of $0.33-0.42 \%$ was found for the MG, maximizing in the near-top layer (MG5, 5-10 cm, 1997-2005) and minimizing in the top layer (MG6, 0-5 cm, 2005-2013). ES exhibited a TOC content ranging from $0.31 \%$ at the top layer $(\mathrm{ES} 6,0-5 \mathrm{~cm}$ ) to $0.49 \%$ at the near-top layer (ES5, $20-25 \mathrm{~cm}$ ). In the case of PT, TOC ranged from $0.10 \%$ to $0.22 \%$ with a maximum at the middle layer (PT3, 15-20 cm, ca. 1981-1989) and a minimum at the top layer (PT6, $0-5 \mathrm{~cm}$, ca. 2005-2013). The fact that TOC maximized at the near-top layers of the cores, except PT, partly suggested that anthropogenic pressure on the river was heaviest in the period ca. 1997-2005. The prevalence of low TOC in the cores may be linked to poor adsorption capacity of organic carbon (OC) towards the coarse solid matrix characteristic of the sheltered basin morphology of the Niger Delta dominated by the sand fraction (SI-1: Oyo-Ita et al. 2016) and low primary productivity (Camachor-Ibar et al. 2003; Dominguez et al. 2009; Oyo-Ita and Oyo-Ita 2013).

TN content in sediments is an indication of the contribution of aquatic flora (Gonzalez-Vila et al. 2003). The values for the cores were low $<0.05 \%$, suggesting a minor contribution from aquatic flora to the $\mathrm{OM}$ composition in the sediment (Fig. 2 b). Atomic $\mathrm{C} / \mathrm{N}$ profiles for the four cores revealed a wider range of 7.81-31.32 for AF and ES than for PT and MG (3.25-16.51), all maximizing in the top layers (Fig. 2 c). Oyo-Ita and Oyo-Ita (2012) reported a similar high C/N value for the top layer of Ukwa Ibom lake sediment, SE Nigeria and attributed the elevated level to greater wash-in of land-derived OM following pave-road extension exercise that involved tree logging/forest clearing. The elevated $\mathrm{C} / \mathrm{N}$ scenario at the top layers here most likely reflected the effect of flood associated with the recent intense rainfall occasioned by global climate change, carrying larger amounts of land-derived debris to the river.

\subsection{Vertical Distribution, Sources and Historical Trends of N-Alkanes}

The aliphatic fractions of the cores comprised of $n$-alkanes in the range $\mathrm{C}_{12}-\mathrm{C}_{37}$, generally suggesting different 
contributions from both biogenic (terrestrial/microbial) and petroleum sources. The $n$-alkanes concentrations for the four cores ranged from $12.51 \mathrm{ng} / \mathrm{g}$ dry weight $(\mathrm{dw})$ in ES core for $\mathrm{C}_{12}$ at the top layer $(\mathrm{ES} 6,0-5 \mathrm{~cm})$ to $426.72 \mathrm{ng} / \mathrm{g} \mathrm{dw}$ for heptadecane $\left(\mathrm{C}_{17}\right)$ at the near-top layer (AF5, 5-10 cm, ca. 1997-2005) of the AF core, with an overall mean of $174.11 \pm 12.25 \mathrm{ng} / \mathrm{g} \mathrm{dw}$ (SI-1). Marked concentration levels $(406.01 \mathrm{ng} / \mathrm{g} \mathrm{dw}$ and $401.87 \mathrm{ng} / \mathrm{g}$ $\mathrm{dw}$ ) were also measured for $\mathrm{C}_{17}$ at the middle layers (ES3 and ES4, 10-15 cm and 15-20 cm) of the ES.

Quantification of homologous $n$-alkane series in the sediment cores allowed the calculations of both carbon maximum $\left(\mathrm{C}_{\max }\right)$ and carbon preference index (CPI). Generally, CPI less and greater than 1 shows $n$-alkanes from biogenic sources of microbial and terrestrial respectively (Simoneit et al. 1991), compared to petrochemical/petroleum (CPI - around 1) sources (Pies et al. 2008).

CPIs calculated for cores AF, MG, PT and ES showed a trend in which the most recent top layers exhibited the highest values $(>1)$. For instance, the observed variation in CPI values for PT in the range $0.90-1.20$ and a maximum at the surface layer (PT6, 0-5 cm, ca. 2005-2013; Fig. 2 d) indicated microbial alteration of fresh plant matter/oil in the lower layers and greater wash-in of terrestrially-derived OM onto the top layer earlier linked to the recent rise in water height following intense rainfall occasioned by climate change, respectively. The near-bottom and bottom layers of PT and MG were largely inundated by microbial input, having CPIs of 0.04 . Generally, the irregularity in CPI patterns down cores reflected changes in energy structure/anthropogenic pressure, enabling deposition of different types and amounts of OM to the river sediment over the last ca. 5 decades.

Besides CPI, a more specific diagnostic parameter that gives indication for the source input of biogenic OM is $\mathrm{C}_{\max } \cdot \mathrm{C}_{\max }>25$ for $n$-alkanes indicates higher plant wax incorporation and $<25$ reflects a strong microbial source input (Mazuerk and Simoneit 1983). Here, $n$-alkanes distributions indicated $\mathrm{C}_{\max }$ at 22 at the bottom layer (MG1, 25-30 cm) of MG, revealing a significant proportion of microbial OM thriving at ca. 1964-1972 (Fig. 3 a, Table 1, Ekpo et al. 2005). In support of this source contribution, Oyo-Ita et al. (2006) and Elias et al. (1997) recorded a predominance of $\mathrm{C}_{22}$ in sediments surface of Cross River estuary, Southeastern Nigeria and in the Amazon shelf and Pacific hydrothermal system, respectively. These authors attributed such occurrence to bacterial alteration of algal detritus. The emergence of land-derived OM thereafter became enhanced at the top most layer (MG6, 0-5 cm).

In the case of ES, $C_{\max }$ at 14, 22, 24 and odd/even predominance in the range $\mathrm{C}_{25}-\mathrm{C}_{35}$ was apparent at the bottom layer $(\mathrm{ES} 1,25-30 \mathrm{~cm})$. This distribution reflected a mixed source of a higher proportion of aquatic microbial over land-derived OM input (Fig. 3 b). The trend persisted thereafter until ES4, 15-20 cm when emergence of $\mathrm{C}_{17}$, a marker indicative of algal growth (Pastor et al. 2001) became apparent (Fig. $3 \mathrm{c}$ ). Although radiometric analysis was not possible for the ES core, going by the data obtained for other cores, this sediment interval almost coincided with the period of occurrence of eutrophication (excessive growth of macro-algal e-water hyacinth) towards the estuarine portion of the river, a consequence of effluents discharges from a fertilizer plant ca. $4 \mathrm{~km}$ from the Afam power station (Guardian Newspaper, $12^{\text {th }}$ July 1989). However, a dramatic change occurred in the OM fluxes at the most recent top layer (ES6, 0-5 cm) where $C_{\max } 27,29$ and 31 prevailed (Fig. $3 \mathrm{~d}$ ). This later pattern is characteristic of higher proportion of vascular plant wax influx to the top layer (Elias et al., 1997; Oyo-Ita et al. 2010). An additional OM input to the top layer reflected in $\mathrm{C}_{\max }$ at 19 , pointed to a bacterial source (Ittekkot, 1988).

In comparison, biogenic OM flux to the AF did not vary remarkably down core $\left(\mathrm{C}_{\max }-14,20,27,29\right.$ and 31), revealing a fairly constant $\mathrm{OM}$ input from both microorganisms and vascular higher plant, except at the near-top layer (AF5, 5-10 cm; Fig. 4 a) deposited ca. 1997-2005. At this near-top layer, additional OM sources $\left(\mathrm{C}_{\max }\right.$ at 17 , 19,21) occurred, characteristic of algal and bacterial OM inputs (Aboul-Kassim and Simoneit, 1996). Field observation revealed that the near-top layer $(\mathrm{AF} 5 ; 5-10 \mathrm{~cm})$ of AF had the smell of oil, supported by the occurrence of a marked unresolved complex mixture (UCM) in the layer (Fig. 4 a). The presence of UCM in aquatic sediment is an indication of relative contribution of petroleum hydrocarbon and/or biodegraded mixture of hydrocarbon. The heavy impact by petroleum hydrocarbons in the period ca. 1997-2005 was linked to frequent and intensive oil bunkering activity and/or oil pipeline vandalism by the Niger Delta militia groups. According to Okpo and Eze, (2012), 'in June 1998, a 16-inch underground Shell pipeline burst, discharging ca. 800,000 barrels of oil into the area'. As in our case study, the pronounced UCM in sediment cores revealed variations in local histories of petroleum hydrocarbons delivery to the study area (Meyers, 2003).

In the case of core PT, no distinct UCMs were apparent in any of the layers (Fig. 4 b, c) probably due to the fact that the core was obtained upstream relative to the site where illegal petroleum refining takes place. This implies that contamination by petroleum hydrocarbons in the last ca. 5 decades was not widespread but rather was 
localized or confined within small areas. In other words, long-range water current trajectory did not play a major role in the distribution of petroleum hydrocarbons in the river in the last ca. 5 decades. Hence, the effect of oil exploitation around the study area from the time of first discovery of commercial quantity of oil in Nigeria in 1956 was not widespread. The near-top layer (PT5, 5-10 cm) of PT exhibited $\mathrm{C}_{\max }$ at $\mathrm{C}_{22}$ and $\mathrm{C}_{24}$ with an even/odd predominance in the range $\mathrm{C}_{12}-\mathrm{C}_{26}$, characteristic of microbial input (Table 1; Fig. 4 b). Sediment samples with specific predominance of organisms input including bacteria and diatoms have been reported (e.g. Simoneit et al. 1991; Elias et al. 1997; Ekpo et al. 2005).

Here again the recent rise in water level experienced in 2012 following intense rainfall resulted in greater wash-in of land-derived OM to the top layer (PT6, 0-5 cm, $\mathrm{C}_{\max }$ at the 29; Fig. $4 \mathrm{c}$ ) of PT core. In specific terms, a predominance of $\mathrm{C}_{31}$ in sediments indicates that the watershed is populated by grasses, whereas $\mathrm{C}_{27}$ or $\mathrm{C}_{29}$ is more abundant in sediments in areas where trees dominate (Cranwell et al. 1987; Vogts et al. 2012). On the basis of this source assignment, the watersheds of AF and ES sites were populated by grasses and trees, those of the MG and PT sites were more populated by trees. However, recent study shows that most of the $\mathrm{C}_{\max }$ applications have been based on a narrow set of data that cannot address intra- and inter-plant variability. A more widespread analysis of data on trees and grasses of different species from different locations of the world shows that $\mathrm{C}_{27}, \mathrm{C}_{29}$ and $\mathrm{C}_{31}$ are highly variable among plants, causing the chemotaxonomic differentiation between woody plants and grasses challenging to determined based on $n$-alkane abundances (Bush and Mcinerney 2013).

To determine the proportion of higher plant-/macrophyte-derived $\mathrm{OM}$ relative to microbial (bacterial-/phytoplankton-derived) $\mathrm{OM}$ in the cores, long chain hydrocarbon $\left(\mathrm{C}_{25}-\mathrm{C}_{35}\right)$ over short chain hydrocarbon $\left(\mathrm{C}_{14}-\mathrm{C}_{24}\right.$; $\left.\mathrm{LHC} / \mathrm{SHC}\right)$ ratios values were calculated and ranged from 1.01 to 1.84 for core $\mathrm{MG}$, indicative of an admixture of almost equal proportion of higher plant/macrophyte and phytoplankton/bacteria in lower layers and a slightly higher proportion of higher plant/macrophyte vs. phytoplankton/bacteria in the upper layers (Table 1). The data support the earlier source assignment from CPI and $\mathrm{C}_{\max }$ for these layers. On the other hand, a relatively higher proportion of land-/macrophyte-derived OM was generally found for core PT than for MG with LHC/SHC ranging from 1.1 to 2.3 (Table 1). PT5, for instance, with intermediate LHC/SHC value (1.1) also indicated a mixed source scenario of almost equal contributions from land-/macrophyte-derived and phytoplankton-/bacteria-derived OM.

The ES core exhibited LHC/SHC values ranging from 0.7 to 2.7 with a minimum at the middle layer (ES4, $15-20 \mathrm{~cm}$ ), indicating a dominant microbial-derived OM input (e.g. algae). The result was in agreement with the $\mathrm{C}_{\max }$ and CPI source data earlier assigned to the layer. Other layers of the ES core exhibited intermediate values, still supporting a mixed source scenario of almost equal contribution from land-/macrophyte-derived and microbial-derived OM, except at ES2 $(20-25 \mathrm{~cm}, 2.3)$ and ES6 $(0-5 \mathrm{~cm}, 2.7)$, which indicated a greater input from land-derived OM.

LHC/SHC values for the AF core were in the range $1.1-2.4$ with terrestrially-derived OM dominating overall. However, evidence of a relatively enhanced input from microorganisms (e.g. petroleum inhabiting bacteria and algae) was apparent at the near-top layer $(\mathrm{AF} 5,5-10 \mathrm{~cm})$ reflected in an intermediate $\mathrm{LHC} / \mathrm{SHC}$ value of 1.1 .

To further characterize the sources of OM in the study area, the proxy parameter, $\mathrm{P}_{\mathrm{aq}}$, was calculated (Table 1). $\mathrm{P}_{\mathrm{aq}}$ reported by Ficken et al. (2000) expresses the relative proportion of mid-chain $\left(n-\mathrm{C}_{23}, n-\mathrm{C}_{25}\right)$ to long-chain length homologues $\left(n-\mathrm{C}_{29}, n-\mathrm{C}_{31}\right)$. According to the interpretation, $\mathrm{P}_{\mathrm{aq}}$ values between 0.4 and 1.0 are indicative of a high contribution from submerged/floating aquatic macrophytes, while between 0.1 and 0.4 , they correspond to emergent terrestrial higher plant'. Here, $\mathrm{P}_{\mathrm{aq}}$ values for core $\mathrm{MG}$ were in the range $0.25-1.0$, maximizing in the bottom layer (MG1, 25-30 cm; 1964-1972), indicating a greater contribution from submerged/floating macrophytes to the bottom layer. On the other hand, a range of $0.35-0.61$ was calculated for core PT, minimizing at the near-top layer (PT5, 5-10 cm, 1997-2005), indicating higher contribution from higher plant vs. macrophyte to the near-top layer, and a maximum at PT3 indicative of higher contribution from macrophyte over higher plant to the middle layer. A $P_{\mathrm{aq}}$ range of 0.29 - 0.51 for core ES, with almost all the layers having about equal proportions of higher plant-derived and macrophyte-derived OM, except at ES3 $(15-20 \mathrm{~cm}, 0.31)$ and ES6 $\left(0-5 \mathrm{~cm} \mathrm{0.29)}\right.$ apparently influenced more by higher plant wax input. A $\mathrm{P}_{\mathrm{aq}}$ range of $0.30-0.44$ for core AF indicated a greater contribution from higher plants at AF3, AF4 and AF6, while the other layers exhibited values characteristic of almost an equal proportion of macrophyte and higher plant input.

\subsection{Vertical and Historical Distributions of Isoprenoid Hydrocarbons and Triterpanes}

Pristane $(\mathrm{Pr})$ and phytane $(\mathrm{Ph})$ were detected in relatively high abundance in the aliphatic fractions of the four cores. The concentrations ranged from $0.46 \mathrm{ng} / \mathrm{g} \mathrm{dw}$ at the near-bottom layer $(\mathrm{PT} 2,20-25 \mathrm{~cm})$ of PT for Ph to $114.33 \mathrm{ng} / \mathrm{g} \mathrm{dw}$ at the middle layer (ES3, 15-20 cm) for Pr, with an overall mean of 78.71 $\pm 43.22 \mathrm{ng} / \mathrm{g}$ (SI-3). 
High $\mathrm{Pr} / \mathrm{Ph}$ values (e.g. 8-11) have been reported to be characteristic of biogenic hydrocarbons source and low ranked coal, while low values are the result of oils (e.g. <2) and high ranked coal (e.g. < 8; Pies et al. 2008). $\mathrm{Pr} / \mathrm{Ph}$ for cores ES and AF ranged from 0.43 at the middle layer $(\mathrm{AF} 3,15-20 \mathrm{~cm})$ of $\mathrm{AF}$ to 1.25 at the middle layer $(\mathrm{ES} 4,10-15 \mathrm{~cm})$ of ES, reflecting varied inputs from oils to these sites in the last ca. 5 decades.

$\mathrm{Pr} / \mathrm{Ph}$ for cores $\mathrm{MG}$ and $\mathrm{PT}$ was in the range $1.15-4.17$, with minimum and maximum values at the near-bottom (MG2, 20-25 cm) and middle layers (MG4, 15-20 cm) of MG, respectively (Table 1). Although input from oil was evident, the relatively high Pr/Ph values at MG4 (4.17), PT1 (3.75) and PT5 (3.86) were suggestive of input from high ranked Nigerian coal utilization as an energy source to fuel the illegal petroleum refinery process at different time intervals in the remote regions. Field observation revealed debris of coaly material dispersed in the vicinity of the illegal activity site. This scenario implied that the illegal activity had begun ca. $8 \mathrm{yr}$ after the discovery of oil in commercial quantity in Nigeria in 1956 and that the illegal activity was not concentrated at one location in the study area. This means that at certain geologic time-frame, these saboteurs relocated from one area to another, following occasional policing/patrolling of the waterway by the Nigerian Navy to stem the tide of oil bunkering.

To further evaluate the impact of humans-induced activity in the study area in the last ca. 5 decades, evaluation of the types and levels of triterpanes was carried out. Triterpanes such as hopanes, 18a-oleanane (30O) and gammacerane $(30 \mathrm{G})$ are petroleum source marker due to their relatively resistant to environmental degradation in recent sediments (Bouloubassi et al. 2001). Also, Peters and Moldowan, (1993) reported that 'hopanes are abundant in petroleum and sediments, because their precursor hapanoids are important membrane components in living cells and are resistant to degradation during diagenesis'. Thus, the presence of hopanes and other triterpanes such as $30 \mathrm{O}$ and $30 \mathrm{G}$ in contemporary sediments confirms fossil fuel contamination.

The following triterpanes were detected in the four cores; 18 $\alpha$-22,29,30-trisnorneohopane (27TS),

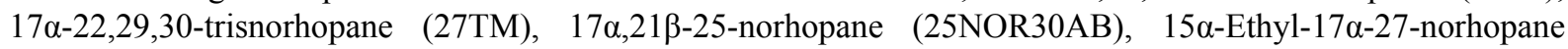

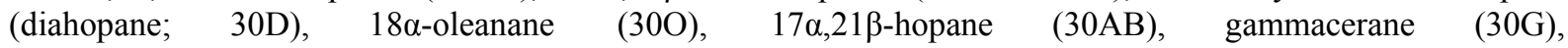

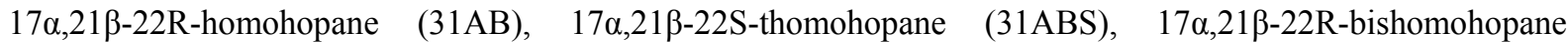
(32ABR), 17 $\alpha, 21 \beta-22 S-b i s h o m o h o p a n e \quad(32 \mathrm{ABS}), \quad 17 \alpha, 21 \beta-22 \mathrm{~S}-$ trishomohopane $\quad$ (33ABS) and $17 \alpha, 21 \beta-22 \mathrm{R}$-trishomohopane (33ABR). The concentrations of triterpanes ranged from $0.34 \mathrm{ng} / \mathrm{g} \mathrm{dw}$ to 119.42 $\mathrm{ng} / \mathrm{g} \mathrm{dw}$, minimizing in $25 \mathrm{NOR} 30 \mathrm{AB}$ at the midle layer (PT4, 10-15 cm) of PT and maximizing in $30 \mathrm{AB}$ at the near-top layer (AF5, 5-10 cm) of AF with an overall mean of 37.31 $\pm 12.64 \mathrm{ng} / \mathrm{g}$ (SI-3).

Generally, the triterpanes exhibited similar distribution pattern in all layers of the four cores except at the bottom $(\mathrm{MG} 1,25-30 \mathrm{~cm}$ ) and top (MG6, 0-5 cm) layers of MG and the near-bottom layer (PT2) of PT. For example, a $\mathrm{m} / \mathrm{z} 191$ chromatogram for the top layer of MG deposited ca. 2005-2013 shows absence of 30O and 25NOR30 (marker compounds characteristic of oils of continental origin - eg Niger Delta oil; Ekweozor et al. 1979; Oyo-Ita et al. 2016) and 27TM as well as the occurrence at low level of $30 \mathrm{G}$ (Fig. 5 a). The later (derived from Genacilinae, an algal species that thrives more on a hypersaline environment) are abundant in petroleum of lacustrine origin (Peter and Moldowan 1993). Its detection at the top layer of the core suggested an input from petroleum products utilization derived from a different source imported into the Nigerian economy. Triterpanes including $30 \mathrm{O}$ and $30 \mathrm{G}$ were not detected in the bottom layer $(\mathrm{MG} 1,25-30 \mathrm{~cm})$ of the MG (SI-2). The scenario suggested that the impact of oil exploitation activity on the sediment deposited about the early 1960 s in the MG area was negligible and that the activity became apparent from early 1970s.

A somewhat different triterpanes distribution pattern was found for most layers of ES, AF and PT cores with the detection of $27 \mathrm{TS}, 27 \mathrm{M}, 30 \mathrm{O}, 25 \mathrm{NOR} 30$ and $30 \mathrm{G}$ (Fig. $5 \mathrm{~b}$ c). This trend implied that an admixture of indigenous and imported oils pervasively impacted the portions of the river in the last ca.5 decades except at the near-bottom layer (PT2, 20-25 cm) of PT. Similar to MG1 profile, a $m / z 191$ chromatogram of PT2 shows absence of triterpanes (Fig. 5 d), revealing that a period of inactivity related to oil exploitation existed at ca. 1972-1981 in the area.

Another prove that Imo River sediments were impacted by hydrocarbons of petroleum origin was again illustrated in the ratio of homohopane index $[22 \mathrm{~S} /(22 \mathrm{~S}+22 \mathrm{R})]$. Homohopane ratio increases with increasing maturity. This imply that immature OM exhibit low homohopane ratios (Gulnay and Korkmaz 2008). Generally, the extended $17 \alpha, 21 \beta$-homohopane $>\mathrm{C}_{31}$ in petroleum showed the epimers at $\mathrm{C}-22$ at an equilibrium ratio $22 \mathrm{~S} /(22 \mathrm{~S}+22 \mathrm{R})$ of ca. 0.6 as reported by Franco et al. (2006). Here, the calculated ratio ranged from 0.57-0.64 with a mean value of $0.60 \pm 0.03$ (Table 1), confirming contamination by matured OM of petroleum hydrocarbons.

Finally, the total aliphatic hydrocarbon (TAH) concentrations for the study were less than those reported for 
sediments from many rivers, estuaries, lakes and seas of the world, ranging from $1,962 \mathrm{ng} / \mathrm{g} \mathrm{dw}$ at the middle layer (10-15 cm, ca. 1989-1997) of MG core to $10,234 \mathrm{ng} / \mathrm{g} \mathrm{dw}$ at the near-bottom layer of PT core $(25 \mathrm{~cm}$, 1972-1981; Fig. 6 a, b, c). For instance, higher levels of TAH were recorded in sediments from Khniss Tunisian coast, Mediterrenean sea (1020 - $2332 \mu \mathrm{g} / \mathrm{g} \mathrm{dw}$, Zrafi et al. 2013); Buffalo river estuary, South Africa (12.59 $1100 \mu \mathrm{g} / \mathrm{kg} \mathrm{dw}$, Adeniji et al. 2017); Tropical Brazilian estuarine system (27.8 -139.5 $\mu \mathrm{g} / \mathrm{g} \mathrm{dw}$, Thias et al. 2013); Lake Washinton, USA (11 - $900 \mu \mathrm{g} / \mathrm{g} \mathrm{dw}$, Stuart et al. 2004).

\section{Conclusions}

Vertical distribution, source and historical variations of aliphatic hydrocarbons in subsurface sediment cores collected from four locations (Mangrove, Afam, illegal petroleum refinery and Estuary) of Imo River, SE Nigeria in the last ca. 5 decades were determined. Evaluation of organic geochemical parameters such as $\mathrm{C} / \mathrm{N}, \mathrm{CPI}, \mathrm{C}_{\max }$, $\mathrm{LHC} / \mathrm{SHC}, \mathrm{P}_{\mathrm{aq}}, \mathrm{Pr} / \mathrm{Ph}, \mathrm{UCM}$ and $22 \mathrm{~S} /(22 \mathrm{~S}+22 \mathrm{R})$ homohopane as well as triterpanes distributions enabled $\mathrm{OM}$ source characterization and anthropogenic changes to be studied.

The results revealed inputs from biogenic (aquatic and/or terrestrial) and petrogenic OM in almost all layers of the four cores with greater wash-in of land-derived OM to the surface layers (0-5 cm, ca. 2005-2013). Sedimentological and radiometric measurements indicated that this time-frame corresponded with the recent rise in water height/flood associated with intense rainfall event of 2012 occasioned by climate change.

While the impact by petroleum hydrocarbons on the bottom layer of the illegal petroleum refinery core (deposited ca. 1964-1972) showed that oil contamination had begun ca. 8 years after the first commercial discovery of oil in Nigeria in 1956. However, the middle layer of the Estuary core was inundated by macro-algal OM. A relatively pristine depositional environment dominated by aquatic micro-organisms was recorded for the bottom layer of the Mangrove core, while a marked UCM measured at the near-top layer of the Afam core indicated that the heaviest contamination by petroleum hydrocarbons occurred at ca 1997-2005 coinciding with the period of intensive oil bunkering/pipeline vandalism of the Niger Delta militias in the area.

\section{Acknowledgements}

'This study was funded in part by the European Association of Organic Geochemists (EAOG Travel scholarship award, 2012). We are also grateful for the facility provided by the Institute of Environmental Assessment and Water Research, Spanish Council of Scientific Research (CSIC) Barcelona, Spain and ADECYTE as well as the assistance of the Department de Fisica-Institut de Cienciai Technologia Ambientals University at Bellaterra, Spain in the radiometric analysis of our cores at little or no cost (facilitated by J. Albaiges and J. Bayona)'.

\section{References}

Aboul-Kassim, T. A. T., \& Simoneit, B. R. T. (1996). Lipid geochemistry of surficial sediments from the coastal environment of Egypt I. Aliphatic hydrocarbons - characterization and sources. Marine Chemistry, 54, 135-158. https://doi.org/10.1016/0304-4203(95)00098-4

Adeniji, A. O., Okoh, O. O., \& Okoh, A. I. (2017). Petroleum hydrocarbons fingerprints of water and sediment samples of Bufalo river estuary in the eastern Cape Province, South Africa. Analytical Method of Chemistry. https://doi.org/10.1155/2017/2629365

Appleby, P. G., Richardson, N., \& Noland, P. J. (1992). Self-absorption corrections for well-type germanium detectors. Nuclear Instrumental Methods, 71, 228-233. https://doi.org/10.1016/0168-583X(92)95328-O

Arnaud, F., Magand, O., Chapron, E., Bertrand, S., Boës, X., Charlet, M. A., \& Mélières, F. (2006). Radionuclide dating $\left({ }^{210} \mathrm{~Pb},{ }^{137} \mathrm{Cs},{ }^{241} \mathrm{Am}\right)$ of recent lake sediments in a highly active geodynamic setting (Lakes Puyehue and Icalma-Chilean Lake District). Science of Total Environment, 366, 837-850. https://doi.org/10.1016/j.scitotenv.2005.08.013

Bouloubassi, I., Fillaux, J., \& Saliot, A. (2001). Hydrocarbons in surface sediments from the

Bush, R. T., \& McInerney, F. A. (2013). Leaf wax n-alkane distributions in and across Modern plants: Implications for paleoecology and chemotaxonomy. Geochim. et Cosmochim. Acta, $\quad 117, \quad$ 161-179. https://doi.org/10.1016/j.gca.2013.04.016

Camachor-Ibar, V. F., Aveytua-Alczar. L., \& Carriquiry, J. D. (2003). Fatty acid reactivity in sediment cores from the Northern Gulf of California. Organic Geochemistry, 34, 425-439. https://doi.org/10.1016/S0146-6380(02)00211-5

Changiang (Yangtze river) estuary, east China Sea. Marine Pollution Bulletin, 42, 1335-1346.

Cranwell, P. A., Eglinton, G., \& Robinson, N. (1987). Lipids of aquatic organisms as potential contributors to 
lacustrine sediments-II. Organic Geochemistry, 11, 513-527. https://doi.org/10.1016/0146-6380(87)90007-6

Ekpo, B. O., Ebirien, P. F., Okon, D. E., \& Hab, L. M. (2012). Distributions of Fossil Fuel Biomarkers in Sediments as Proxies for Petroleum Contamination of Coastal Environment of the Niger Delta, Southeastern Nigeria. Journal of Applied Science in Environmental Sanitation, 7, 75-86.

Ekpo, B. O., Oyo-Ita, O. E., \& Wehner, H. (2005). Even n-alkanes/alkenes predominances in surface sediments from Calabar River, S.E. Niger Delta, Nigeria. Natur Wissenshaften, 92, 341-347. https://doi.org/10.1007/s00114-005-0639-8

Ekweozor, C. M., Okogun, J. I., Ekong, D. E. U., \& Maxwell, J. R. (1979). Preliminary organic geochemical studies of samples from the Niger Delta (Nigeria)1. Analyses of crude oils for Triterpanes. Chemical Geology, 27, 11-28. https://doi.org/10.1016/0009-2541(79)90100-1

Elias, V. O., Simoneit, B. R. T., \& Cardoso, J. N. (1997). Even n-alkane predominances on the Amazon Shelf and a Northeast Pacific Hydrothermal System. Naturwissenchaften, 84, 415-420. https://doi.org/10.1007/s001140050421

Ezeayim, V., \& Okereke, C. A. (1996). The effect of petroleum activities in Nigerian soil environment. Global Journal of Pure and Applied Sciences, 11, 285-297.

Ficken, K. J., Li, B., Swain, D. L., \& Eglinton, G. (2000). An $n$-alkane proxy for the sedimentary input of submerged/floating freshwater aquatic microphytes. Organic Geochemistry, 31, 745-749. https://doi.org/10.1016/S0146-6380(00)00081-4

Franco, M. A., Vinas, L., Soriano. J. A., de Armas, D., Gonzalez, I. J., Beiras, R., ... Albaiges, J. (2006). Spatial distribution and ecotoxicity of petroleum Hydrocarbons in sediments from the Galicia continental shelf (NW Spain) after the Prestige oil spill. Marine Pollution Bulletin, 53, 260-271. https://doi.org/10.1016/j.marpolbul.2005.10.004

Gonza-lesvila, F. J., Polvillo, O., Boski, T., Moura, D., \& Andres, de J. R. (2003). Biomarker patterns $\quad$ in $\quad$ a time-resolved Holocene/terminal Pleistocene sedimentary sequence from the Gurdiana River estuarine area (SW Portugal/Spain Border). Organic Geochemistry, 34, 1601-1613.

https://doi.org/10.1016/j.orggeochem.2003.08.006

Gulnay, R. K., \& Korkmaz, S. (2008). Organic geochemistry, depositional environment and hydrocarbon potential of the Tertiary oil shale deposits in NW Anatolia, Turkey. Oil Shale, 25, 444-464. https://doi.org/10.3176/oil.2008.4.05

Guo, J. Y., Wu, F. C., Luo, X. J., Liang, Z., Liao, H. Q., \& Zhang, R. Y. (2010). Anthropogenic input of polycyclic aromatic hydrocarbons into five lakes in western china. Environnent and Pollution, 158, 2175-2180. https://doi.org/10.1016/j.envpol.2010.02.018

Ittekkot, V. (1988). Global trends in the nature of organic matter in river suspensions. Nature, 332, 436-438. https://doi.org/10.1038/332436a0

Jaffé, R., Mead, Y., Yu, J., \& Chong, J. (2005). Sediment and soil organic matter source assessment as revealed by molecular distribution and carbon isotopic composition of n-alkanes. Organic Geochemistry, 36, 363-370. https://doi.org/10.1016/j.orggeochem.2004.10.003

Mazuerk, M., \& Simoneit, B. R. T. (1983). Characterization of biogenic and petroleum-derived organic matter in aerosols over remote rural and urban areas. In Keith, L. H. (Ed.), Identification and analysis of organic pollution in air (pp. 353-370). American Chemical Society.

Meyers, P. A. (2003). Application of organic geochemistry to paleolimnological reconstruction: a summary of examples from Laurentian Great lakes. Organic Geochemistry, 34, 261-289. https://doi.org/10.1016/S0146-6380(02)00168-7

Okpo, O. C., \& Eze, R. C. (2012). Vandalization of Oil Pipelines in the Niger Delta Region of Nigeria and Poverty: An Overview. Studies in Sociological Science, 3, 13-21.

Oyo-Ita, I. O., Oyo-Ita, O. E., Dosunmu, M. I., Dominquez, C., Bayona, J. M., \& Albaiges, J. (2016). Sources and distribution of petroleum hydrocarbons in recent sediment of the Imo River, SE Nigeria. Archive Environmental Contamination and Toxicology, 70, 372-382. https://doi.org/10.1007/s00244-015-0237-5

Oyo-Ita, I. O., Oyo-Ita, O. E., Ikip, E. O., Sam, E. S., \& Ugim, S. U. (2017). Source characterization and historical trend of sedimentary PAHs from Refome lake, south-south Nigeria. Aquatic Geochemistry, 23, 377-398. https://doi.org/10.1007/s10498-017-9327-5 
Oyo-Ita, O. E., \& Oyo-Ita, I. O. (2012). PAH depositional history and sources in recent sediment core from Ukwa Ibom Lake, SE. Nigeria. Environmental Geochemistry and Health, 35, 189-199. https://doi.org/10.1007/s10653-012-9475-x

Oyo-lta, O. E., \& Oyo-ita, I. O. (2013). Fatty Acid and Alcohol Distributions and Sources in Surface Sediments of Imo River, Southeast Niger Delta, Nigeria. Environmental and Natural Resources Research, 2, 101-113. https://doi.org/10.5539/enrr.v2n4p101

Oyo-lta, O. E., Ekpo, B. O., Oros, D. R., \& Simoneit, B. R. T. (2010). Distribution and sources of aliphatic hydrocarbons and ketones in surface sediments from the Cross River estuary, S.E. Niger Delta, Nigeria. Journal of Applied Science in Environmental Sanitation, 5, 13-24.

Oyo-lta, O. E., Ekpo, B. O., Umana, U. S., \& Simoneit, B. R. T. (2006). Predominance of n-docosane/docosene as molecular indicators of microbial and recent biogenic organic matter incorporation into surface sediments of Cross River Estuary, S.E Niger Delta, Nigeria. Global Journal of Environmental Science, 5, 43-48. https://doi.org/10.4314/gjes.v5i1.2469

Pastor, D., Sa'nchez, J., Porte, C., \& Albaiges, J. (2001). The Aegean Sea oil spill in the Galicia Coast North West Spain. I. Distribution and fate of crude oil and combustion products in subtidal sediments. Marine Pollution Bulletin, 42, 895-904. https://doi.org/10.1016/S0025-326X(01)00048-0

Peters, K. E., \& Moldowan, J. W. (1993). The Biomarker Guide: Interpreting Molecular Fossils in Petroleum and Ancient Sediments, Prentice Hall, New Jersey.

Pies, C., Hoffmann, B., Petrowsky, J., Yang, Y., Ternes, T., \& Hofmann, T. (2008). Characterisation and source identificationon of polycyclic aromatic hydrocarbons (PAHs) in river bank soils. Chemosphere, 72, 1594-1601. https://doi.org/10.1016/j.chemosphere.2008.04.021

Pinglot, J. F., \& Pourchet, M. (1995). Radioactivity measurements applied to glacier sand lake sediments. Science of Total Environment, 174, 211-23. https://doi.org/10.1016/0048-9697(95)04779-4

Saliot, A., Mejanelle, L., Scribe, P., Fillaux, J., Pepe, C., Jabaud, A., \& Dagaut, J. (2001). Particulate organic carbon, sterols, fatty acids and pigments in the Amazon Rivers system. Biogeochemistry, 53, 79-103. https://doi.org/10.1023/A:1010754022594

Simoneit, B. R. T., Sheng, G., Chen, X., Fu, J., Zhang, H., \& Xu, Y. (1991). Molecular marker study of extractable organic matter in aerosols from the urban areas of China. Atmospheric Environment, 25, 2111-2129. https://doi.org/10.1016/0960-1686(91)90088-O

Sinninghe-Damsté, J., Kenig, F., Koopmans, M., Koster, J., Schouten, S., Hayes, J., \& De-leeuw, J. (1995). Evidence for gammacerane as an indicator of water column stratification. Geochim. et Cosmochim. Acta, 59, 1895-1900. https://doi.org/10.1016/0016-7037(95)00073-9

Sojino, S., Wang, J., Sonibare, O., \& Zeng, E. (2010). Polycyclic aromatic hydrocarbons in Sediments and soils from oil exploration areas of the Niger Delta, Nigeria. Hazardous Material, 174, 641- 647. https://doi.org/10.1016/j.jhazmat.2009.09.099

Strauss, J., Schirrmeister, L., Mangelsdorf, K., Eichhorn, L., Wetterich, S., \& Herzschuh, U. (2015). Organic-matter quality of deep permafrost carbon - a study from Arctic Siberia. Biogeoscience, 12, 2227 2245. https://doi.org/10.5194/bg-12-2227-2015

Stuart, A. W., James, F., Caroline, A. M., Yves, G. S., Clark, R. A., \& Peter, R. L. (2004). Hydrocarbons in lake Washington sediments. A 25 year in retrospective in an urban lake. Environmental Science and Technology, 38, 431-439. https://doi.org/10.1021/es0343149

Thias, R. S., Silvia, R. P., Gertrud, S., Bastiaan, A. K., \& Debora, A. A. (2013). Evaluation of anthropogenic inputs of hydrocarbons in sediment cores from a tropical Brazilian estuarine system. Microchemistry Journal, 109, 178-188. https://doi.org/10.1016/j.microc.2012.02.012

Vogts, A., Schefub, E., Badewein, T., \& Rullkötter, J. (2012). n-alkane parameters from a deep sea sediment transect off southwest Africa reflect continental vegetation and climate conditions. Organic Geochemistry, 43, 109-119. https://doi.org/10.1016/j.orggeochem.2012.03.011

Zhang, R., Zhang, F., \& Zhang, T. (2013). Sedimentary records of PAHs in a sediment core from tidal flat Haizhou Bay, China. Science of Total Environment, 450, 280-288. https://doi.org/10.1016/j.scitotenv.2013.02.029

Zrafi, I., Bakhrouf, A., Rouabhia, M., \& Saidane-Mosbahi, D. (2013). Aliphatic and aromatic biomarkers for 
petroleum hydrocarbons monitoring in Khniss Turnisian-coast (Mediterranean Sea). Procesia Environmental Science, 8, 211-220. https://doi.org/10.1016/j.proenv.2013.04.027

\section{Copyrights}

Copyright for this article is retained by the author(s), with first publication rights granted to the journal.

This is an open-access article distributed under the terms and conditions of the Creative Commons Attribution license (http://creativecommons.org/licenses/by/4.0/). 